\title{
Government interventions in sustainable supply chain governance: Experience in Dutch front-running cases
}

\author{
W.J.V. Vermeulen ${ }^{\mathrm{a}, *}$, M.T.J. Kok ${ }^{\mathrm{b}}$ \\ a Utrecht University, Faculty of Geosciences, Copernicus Institute of Sustainable Development, Utrecht, The Netherlands \\ b PBL Netherlands Environmental Assessment Agency, Bilthoven, The Netherlands
}

\section{A R T I C L E I N F O}

\section{Article history:}

Received 6 April 2011

Received in revised form 21 March 2012

Accepted 1 April 2012

Available online 11 May 2012

\section{Keywords:}

Supply chain

Sustainable products

Integrated product policy

Government

Certification

Global trade

\begin{abstract}
A B S T R A C T
Numerous multi-actor governance systems have recently emerged, ensuring sustainability of international traded products. Business and civil society actors play a dominant role in initiating and governing 'sustainable supply chain governance systems' (SSCG systems). Within specific product markets we see the emergence of various competing SSCG systems.

This has led to debates on effectiveness, transparency and legitimacy of these forms of self-governance in the market. These developments also call for a debate on appropriate roles for (national) governments.

Most of the academic literature in this field focuses on methodologies for supply chain governance and their impacts, but hardly addresses the roles taken on by governments and effectiveness of possible government interventions. This article combines analysis of market dynamics in the timber and coffee product chains with policy analysis, integrating approaches from the research fields of sustainable business and policy analysis.

The article shows how competition between various sustainable supply chain governance systems in The Netherlands has resulted in recent market breakthroughs, while initially government interventions were very limited and diverse.

The article suggests an approach for more systematic analysis of these dynamics and the roles of various actors, by identifying both the 'public policy cycle' and the 'private policy cycle'.
\end{abstract}

(c) 2012 Elsevier B.V. All rights reserved.

\section{Introduction}

Growing numbers of multi-actor governance systems aiming for sustainable products have emerged in international supply chains of specific products, such as timber, fruits, coffee, and cotton, during the last two decades (Blowfield, 2003; Bush et al., 2009; Freidberg, 2003; Mefford, 2010). Business and civil society actors play a dominant role in initiating and governing these systems. Within specific product markets we also see the emergence of various competing systems (for more details, see Vermeulen et al., 2010). More recently this development has started to gain considerable momentum. In the last five years we have entered a new phase in which the production of sustainable products has started to become a mainstream market activity (Danse and Wolters, 2003; Dolan and Humphrey, 2004; Ras and Vermeulen, 2009; Raynolds, 2008).

The emergence of global sustainable supply chain governance started with small 'enlightened' entrepreneurs, often with a history in civil society, bypassing the dominant mainstream supply chains. Starting in the late 1970s and 1980s, fair trade initiatives began to

\footnotetext{
* Corresponding author.

E-mail address: w.j.v.vermeulen@uu.nl (W.J.V. Vermeulen).
}

create new and shorter supply chains, linking small-scale producers in developing countries more directly with western consumers (Laine and Laine, 2009; Roberts, 2003; Tallontire, 2009). For this purpose, new cooperatives have been created, as well as new distribution systems in countries such as Finland, Belgium, Germany and The Netherlands (e.g. World Shops, Green Shops) (Low and Davenport, 2005). This is similar to how trade in organic products was originally organised in separate supply chains, bypassing mainstream firms, even dating back to the 1930s. In both types of initiatives (e.g. Max Havelaar and EKO), control systems for securing environmental and social responsibility throughout the value chain were developed and implemented, guaranteeing better prices for small farmers in developing countries (Bitzer et al., 2008; Davies, 2007; Raynolds and Ngcwangu, 2010; Raynolds et al., 2007).

With these approaches, 'bioneers and ecopreneurs' (Schaltegger, 2002) in market and civil society (NGOs) have been filling a 'regulatory vacuum'. Western governments are mostly unable to prevent the increasing shift of environmental impacts towards developing countries that result from growing international trade (PBL, 2008; Nijdam and Wilting, 2003). Other governments cannot dictate production conditions in developing countries. They have to follow the long route of international agreements negotiated by supranational institutions (WTO, UN, and OECD), with only limited implementation powers, and await effective implementation by national governments. 
These diverse modes of organising international trade within a firm's supply chain have gained attention in various disciplines, all with their own key questions and perspectives. In economic geography they have been referred to as 'supply chain governance' (Coe et al., 2004; Gereffi, 1999; Kaplinsky, 2000), with various possible strategies to be applied by leading firms. In business management the rationales of diverse strategies for supplier collaboration are studied from the perspective of assuring value creation and business success (Porter, 2011; Williamson, 2008). In these disciplines, strategies for assuring environmental and social responsibility throughout the value chain are usually not explicitly addressed. Simultaneously, supply chain management has also been studied by environmental scientists and scholars in environmental business management, as an ecological and logistic challenge (Hall, 2000; Quakernaat and Weenk, 1993; Seuring, 2004; Seuring and Muller, 2008). In this article, we intend to link these various approaches in order to better understand governance aimed at sustainability in global product chains. We use the concepts of value chain, supply chain and product chain, originating from these different disciplines, more or less as synonyms, with the first two in literature often having a more limited scope, excluding consumer and post-consumption activities (see also Vermeulen and Ras, 2006, p. 247). A more extensive discussion of the literature on sustainable supply chains has been given in a recent article: there we distinguished three generations of business and civil society responses in assuring sustainability in international supply chains: single-firm approaches, joint product-chain arrangements, and cross-sector joint product-chain arrangements, and developed an integrating theoretical framework that also served as a starting point for this study (Vermeulen, 2010). In this article, this framework of business dynamics is extended with the roles that governments may have in international supply chains.

The recent developments in market self-regulation gave rise to several debates on what could be expected of effectiveness (Arce, 2009; Barrientos, 2007; Damette and Delacote, 2011; Perfecto et al., 2005), economic benefits for producers in developing countries (Gobbi, 2000; Valkila, 2009), transparency (Perl and Vorbach, 2009; Svensson, 2009), the growing demand for sustainable products (Sell et al., 2006), global distribution of value (Kaplinsky, 2000), the legitimacy of such forms of self-governance (Albersmeier et al., 2009; Alvarez et al., 2010; Auld, 2010; Meaton and Young, 2003; Pagell and $\mathrm{Wu}, 2009$; Reuter et al., 2010), and on approaches to performance measurement (Erol et al., 2011; Foran et al., 2005; GerbensLeenes et al., 2003). Self-regulating initiatives have been taken by businesses and NGOs in the context of the underlying problem of the 'regulatory vacuum', in which western governments cannot effectively address unsustainable practices of suppliers in other countries (often developing countries). This has also brought on the debate about what would be the most suitable roles for (national) governments in these developments (Mcdermott et al., 2008; Seuring and Müller, 2008; Teegen et al., 2004).

In this article we analyse the relation between 'voluntary' activities in the market and roles taken on by governments. So far, the roles that governments play in the emergence of these systems, as well as the policy implications of successful mainstreaming of such systems, have hardly been analysed. However, such an analysis would be very relevant, because the academic fields of business management and economic geography, and policy sciences have hardly been integrated, although both fields apply a concept of 'governance'. Both do so by way of concerted action by various interdependent actors, but in largely different contexts and not in connection with each other. An analysis of specific cases of sustainable supply chain governance may help to bridge this gap. This brings us to the following research questions:

Which strategies and instruments has the Dutch Government applied to promote the sustainability performance of products traded in global supply chains and how have the effectiveness of these strategies and instruments been evaluated?

We define sustainable supply chain governance systems (in short: SSCG systems) as 'forms of cooperation of market actors in (international) supply chains, possibly together with non-market actors, in improving the environmental and social conditions of production operations' (following Vermeulen and Seuring, 2009; Vermeulen, 2010). Such governance systems, in principle, can be restricted to a single country, if a full supply chain is entirely located within that country. However, in a very large portion of all supply chains, due to the globalised economy, sourcing may start anywhere around the globe, with final consumption taking place in a totally different location. From the perspective of sustainable development, it is especially this international dimension and the distributive aspects (Kaplinsky, 2000) that make us focus on governance systems for products that are mostly imported into developed countries from developing countries.

In the article, we first discuss the consequences of private-sectorinitiated governance for policy analysis. We analyse the link between the various concepts of 'governance' and their implications for analysing sustainable supply chain governance (Section 2). After explaining our research methods (Section 3), the main market developments are discussed for the two product chains (Section 4), followed by the results of the analysis of government activities. This analysis subsequently allows us to further reflect on the governance of selfregulating markets' and to link the governance concepts applied in the academic fields mentioned above.

\section{Governance: Private-Actor Activity Versus Government Activity}

From the 1970s onwards, diverse forms of environmental governance have emerged in many western countries. The concept of environmental governance refers to the means by which society determines and acts on goals and priorities related to the management of the environment. This includes rules and instruments, both formal and informal, which govern human behaviour as well as processes leading to decisions and implementation and the relevant institutional settings (Lemos and Agrawal, 2006).

According to Durant et al. (2004), the concept of environmental governance relates to the increasingly collaborative nature of policy formulation and implementation. 'In this vein, a wide array of third parties (for example, actors in the profit sector, the non profit sector, and civic society) in addition to government agencies, comprise non-hierarchical networks of actors wielding a variety of policy tools (for example, rules and regulations, subsidies, and information) to address diverse, complex, and evolving environmental and natural resources problems' (Durant et al., 2004, pp. 22-23).

The debate on environmental governance is part of a broader governance debate in social and political sciences, which started in the late 1970s and has further intensified since the 1990s (e.g. see Hanf and Scharpf, 1978; Kjaer, 2004; Marin and Mayntz, 1991; Rhodes, 1997; Stoker, 1998; Van Kersbergen and Van Waarden, 2004). Governance is a concept that is often used in studies of public policy to reflect the notion that the public sector is not the only controlling actor when it comes to the solution of collective-action problems and the provision and production of public goods. During the last decades, more attention has been given to the relationships between state and society, particularly to how government, market, and civil society interact (Kooiman, 2003, p. 5; Pierre, 2000).

Thus, apart from governments, civil society actors also play a role in the promotion of public goods, as well as business, science and the mass media. Some have claimed that, in order to stimulate environmentally sound decisions, there must be a trend towards the organisation of cooperative learning processes among government representatives, businesses, civil society and science (Driessen and 
Glasbergen, 2002; Durant et al., 2004). Especially in western societies, government authorities at different levels tend to assure themselves of the cooperation of third parties - both from civil society and the private sector - with direct interests in the issues at stake (Vermeulen et al., 1997). We also found examples of state actors seeking to promote the self-regulating capacity of private parties, stimulating them to tackle sustainability issues that are considered collective problems (Glasbergen and Groenenberg, 2001). In doing so, private parties from the market and from civil society are assigned a more prominent and - important here - sometimes even a protagonist role in the public arena.

These new types of governance highly differ from traditional command and control methods of steering, as far more discretionary powers are left to non-state actors, but still reflect a relatively strong initiating role for governments at various levels. A strong protagonist role for the market in establishing public goods is found in various forms of self-regulation (Gunningham and Grabosky, 1998). The creation of sustainable supply chain governance systems, addressed in this article, may be a strong form of self-regulation, as in many cases the creation of these governance systems is not initiated by any government agency, but by actors in the market and/or within civil society.

With this shift towards self-regulation, a re-assessment of the actual roles of government agencies is needed (Andrews, 1998; Smith and Fischlein, 2010). If other actors are taking the initiative to 'address diverse, complex, and evolving environmental and natural resources problems', how can governments support, facilitate or even monitor and assure success of these 'self-regulated' initiatives? To address this question the general approach in policy analysis must be adjusted, in which governments are initiators of collective action and policy instruments are aimed at changing private actors behaviour in line with public goals, and where businesses and citizens are the 'recipients' of government activity. The new situation with private sustainable supply chain governance systems reverses this relation between governments and private actors in society (business, NGOs, and consumers). For this reason we developed an assessment framework based on that of policy science, but adjusted to this new situation. This includes an analysis of the 'policy cycle', and of different 'policy strategies' and of 'policy instruments' applied in relation to the emergence and implementation of SSCG systems.

In assessing the role of government as a public policymaker, the 'policy cycle' is traditionally described as a number of processes, at least including (1) agenda setting, (2) problem analysis and goal setting, (3) specification of alternatives from which a choice is to be made, (4) an authoritative choice among those specified alternatives, (5) implementation of a decision and (6) finally evaluating the level of goal achievement (Van de Graaf and Hoppe, 1996).

We define 'policy instruments' in the traditional way as "everything policy makers use or can use to achieve behavioural change from societal actors that will contribute to attaining public policy goals". This definition in large resembles the classical definition posed by Hoogerwerf and Bressers and Klok (Bressers and Klok, 1987; Hoogerwerf, 1990; Klok, 1989). It stresses two points; first, the concept is restricted to state activities addressed to the behaviour of other societal actors (so policy planning and strategic documents are not seen as instruments) and second, it stresses the orientation on changing the behaviour of these others (producers, consumers, NGOs etc.). In this way the concept of 'policy instruments' has a limited scope, each instrument just being one of the things governments (can) do to achieve goals.

In practice, multiple instruments are applied simultaneously, addressing specific actors in society. Coherent sets of instruments can be labelled as 'policy strategy'. The 'strategy' concept stresses various aspects, like a consciously intended course of action and consistent combination of activities; but also smart manoeuvres and tricks to achieve goals, and taking a specific position, locating the organisation in its external context with a specific role, based on a specific way of perceiving the world (Mintzberg, 1987). Thus the concept of strategy captures the possible choices between different ways of achieving the same public goals.

Developments in environmental policies have been described as an evolution through three main categories of strategies and instruments, each focussing on a specific constellation of the action network. Comparable distinctions can be found in the international literature (see Keijzers, 2000; Lemos and Agrawal, 2006; Mont and Dalhammar, 2005; Vermeulen, 2002a):

- Strategy 1: central regulation by means of coercion and incentives (government initiates);

- Strategy 2: interactive regulation and internalisation (government and market collaborate);

- Strategy 3: facilitating self-regulation (market and civil society initiate).

These strategies have been translated for this situation of research on self-regulation and we identified different classes of policy instruments applied in connection to each. In the first two strategies governments are in the lead and apply instruments to address other actors. In this context classifying policy instruments in the traditional way is useful. Relevant classes of policy instruments are regulation, economic instruments and communicative instruments (Glasbergen, 1992).

With the third strategy, facilitating self-regulation, the position of governments has changed. Using the 'policy strategy' concept discussed above in its meaning of a position and perspective taken, it implies that governments see themselves in position outside the playing field. Not as a coach or referee, but rather in a more distant position, with a perspective on using the forces in the societal and competitive game in the markets for sustainable products, using smart ploys and tricks to make the game attractive. To facilitate this market game they use a set of instruments, that partly covers the same categories as in Strategies 1 and 2, but they do not address social actors directly (producers, consumers). Rather they support existing and new actors in their activities, with subsidies, with supportive communicative activities or even by creating new actors.

In this third strategy markets and civil society have taken the initiative to create self-regulation systems, but governments still play, in various ways, a supporting and facilitating role responding to the actors in the game. In that sense this situation fits in what Jordan et al. (2005) have called 'strong governance' in contrast to 'strong government'.

However, in the specific field of this study, sustainable products, there is one additional strategy. Since governments in practice always also are an important economic actor in the market place, in their role of institutional consumer, the 4th strategy is that of an active institutional consumer. We see a history of initially voluntary approaches for all departments and levels of government, combined with communication programmes on sustainable procurement (Preuss, 2009; Walker et al., 2008). In The Netherlands, this has recently been replaced with a mandatory approach, thus tactically using its dominant position in many product markets to leverage a breakthrough for sustainable products.

A last step in adjusting the tools of policy analysis for this study to be able to apply it on self-regulation, is translating the concept of 'policy cycle' to private actor initiated self-regulation. We need to distinguish the 'private policy cycle' from the 'public policy cycle'. Here it is essential to recognise that private actors, independent of governments, can and have already initiated such activities in practice. So, for analysing the functioning of sustainable supply chain governance systems, initiated by private actors (market and/or civil society), we break this down as their private policy process, in the hands of individual companies or collaborating companies and civil society organisations. It consists of four sequential stages: initiation and development, decision-making, implementation by (demand and supply side) businesses and their evaluating 
market impacts (see also Goldbach et al., 2003). These four stages in principle include comparable 6 steps as described above for 'public policy cycle', with the first three steps (-1- agenda setting, -2- problem analysis and goal setting, -3- choosing from alternatives) in the first stage, and the fourth step (decision making) in the second stage. However, in supple chain governance private actors play the central role. The core questions in the two preparatory stages refer to the extent to which and how governments have been involved in these first stages of the 'private policy process'. Then, after formalisation of the supply chain governance system by its founding actors by applying their selfdesigned rules, the third and fourth stages also cover the same two final steps as in the public policy cycle; the implementation and performance evaluation, but this time governed by private actors: the implementation and performance evaluation. This has been illustrated in Fig. 1. This figure has served as a practical tool in the analysis, identifying the various direct and indirect roles of national governments in each stage.

\section{Research Methods}

This study has an exploratory character, focussing on two specific product groups to determine the strategies and instruments applied in practice in the last 20 years by various ministries of the Dutch government. The Netherlands provides a good context for addressing the research question. It has a long history of environmental policy specifically addressing environmental improvement of products, working with a supply chain approach (European Commission, 2003; Keijzers, 2000; Rubik and Scholl, 2002; Vermeulen, 2002a, $2002 b, 2006)$. In the 1990s it formulated as one of the first countries an integrated environmental product policy, closely collaborating with industries and NGOs. Various certification systems for sustainable products have been initiated (amongst others) by Dutch businesses or NGOs (Max Havelaar, UtZ Certified, GlobalGAP, see Text box 2).

The following criteria for the selection of the two product groups were analysed in this study:

- Does it fit within the priorities set by the Dutch Government?

- Does it have the ability to illustrate both the development and implementation stages of applying forms of self governance?

- Is it illustrative of both environmental and social-ethical issues?

Based on these requirements we selected tropical timber and coffee as our object of study. These product chains have the longest history of implementing forms of self-governance for sustainable production in The Netherlands, and are therefore good cases to illustrate developments in the market (market shares) and policies. These two groups of products differ in the sense that the timber supply
Text box 1

Forest Stewardship Council (FSC)

The FSC was launched in 1990 in the U.S., responding to the slow (international) government action against illegal logging. Consumers, traders and a number of environmental and development organisations established FSC in 1993 in order to use labelling as instrument to change the market. Since then the market share steadily increased, but the emphasis is still in non-tropical timber.

www.fsc.org

PEFC (Programme for the Endorsement of Forest Certification) PEFC was founded in 1999 in Paris by representatives from the market from 11 different countries as an alternative to FSC. Since 2000 PEFC accredited a growing number of national forest management standards.

www.pefc.org

chain is a mixed chain with large amounts of imports to The Netherlands from other European countries, even more than from developing countries, while coffee is solely sourced from developing countries. This distinction is very relevant because the roles taken on and instruments applied by governments are very different if a large part of the sourcing comes from developed countries than when products are sourced from developing countries. In the case of products sourced in developing countries, governments of demand side countries lack the instruments to directly address the sustainability of the mode of production at the supply side of these chains. Developmental concerns also play a bigger role in chains sourced predominantly in developing countries. As these Dutch systems operate internationally, insights from this study are also relevant elsewhere. Review of experiences in UK and Germany confirms this (Vermeulen et al., 2010).

The tropical timber and coffee supply chains were taken as case studies. For each case study we collected up-to-date data on the following aspects:

- a brief overview of global trading trends related to the Dutch imports and exports;

- a history of the emergence of various sustainable supply chain governance approaches (both collaborative and by individual firms) in these product markets;

- the organisational features of these sustainable supply chain governance approaches;

Stages and issues of the functioning of sustainable supply chain governance (SSCG) systems

\begin{tabular}{|c|c|c|c|c|c|}
\hline \multirow{2}{*}{$\begin{array}{l}\text { System } \\
\text { phase }\end{array}$} & \multirow[t]{2}{*}{ 1. Development } & \multirow[t]{2}{*}{ 2. Decision-making } & \multicolumn{2}{|c|}{ 3. Implementation } & \multirow[t]{2}{*}{ 4. Market impact } \\
\hline & & & & em & \\
\hline Actor & $\begin{array}{l}\text { Initiating } \\
\text { parties }\end{array}$ & $\begin{array}{l}\text { SSCG-system } \\
\text { partners }\end{array}$ & $\begin{array}{l}\text { Supply side } \\
\text { firms in } \\
\text { supply chain }\end{array}$ & $\begin{array}{c}\text { Demand side } \\
\text { firms in supply } \\
\text { chain }\end{array}$ & $\begin{array}{l}\text { Consumer } \\
\text { Individuals / } \\
\text { Institutions }\end{array}$ \\
\hline $\begin{array}{l}\text { Key aspects } \\
\text { and issues }\end{array}$ & $\begin{array}{l}\text { - Actors included } \\
\text { - Discourse } \\
\text { - Disclosure }\end{array}$ & $\begin{array}{l}\text { - Who decides? } \\
\text { - Private regulation } \\
\text { - Competing SSCG } \\
\text { systems } \\
\text { - Issue coverage } \\
\text { - Target levels }\end{array}$ & \multicolumn{2}{|c|}{$\begin{array}{l}\text { - Self-assessment } \\
\text { - Compliance } \\
\text { - Auditing } \\
\text { - Verification } \\
\text { - Ecological impacts } \\
\text { - Community impacts } \\
\text { - System (side)impacts }\end{array}$} & $\begin{array}{l}\text { - Awareness } \\
\text { - Reliability } \\
\text { - Buying behaviour }\end{array}$ \\
\hline
\end{tabular}

Fig. 1. Stages and issues in the functioning of sustainable supply chain governance systems (SSCG systems). 
Text box 2

Max Havelaar (Fairtrade NL)

Initiated in 1986 by the Dutch development NGO Solidaridad, Max Havelaar introduced the first Fairtrade products, like coffee in 1988. The number of products has widened, but market share remained stable. In Great Britain last year showed strong growth.

www.maxhavelaar.nl; www.fairtrade.org.uk

GlobalGAP

GlobalGAP was established in 1997 as a system of sustainable supply chains from farm to supermarket. It is not visible on finished products. Supermarkets and their suppliers from more than 100 countries are currently connected. For an increasing number of products standards are developed that suppliers must meet.

www.globalgap.org

UtZ Certified

UtZ Kapeh was created in the mid 1990s originally by Ahold Coffee Company and some others, but has grown into an international organisation (UtZ Certified), which certifies more products (tea, cocoa, and palm oil).

www.utzcertified.org

- historical data on the relative shares of certified products under these various approaches in the Dutch market;

- information about the direct and indirect government support to these sustainable supply chain governance approaches;

- a review of applied policy instruments that would be directly or indirectly related to these sustainable supply chain governance approaches;

- a review of existing evaluation studies addressing these policies.

By using the template presented in Fig. 1, identifying the four stages in the 'private policy cycle', we were able to identify the full spectrum of government activities that have been employed in these two specific supply chains. Using the four government policy strategies distinguished in Section 2, we attributed these policy instruments to these various strategies.

We applied a form of meta-evaluation, using 25 interviews with key stakeholders connected to the most relevant certification systems and governments' representatives, and extensive document analysis as sources of information. Both the most direct responsible officers in various relevant government agencies and certification organisations have been interviewed. Information has been double checked, by looking at available policy documents and by also interviewing officials from NGOs active in the area of sustainable trade in these two product groups. The interviews with open-ended questions were structured using the subjects listed above and Fig. 1.

As a last verification, our preliminary findings have been presented and discussed during a stakeholder workshop, involving many of the interviewees. In total 18 persons, both from various related ministries, key market representative from the coffee and the timber market, NGOs active in these fields and researchers attended this workshop. In this way we have been able to create the full picture of the instruments applied in practice, verified by stakeholders involved.

\section{Market Dynamics in Tropical Timber and Coffee}

Both in the timber and coffee chains there is a long history of fully private initiatives in The Netherlands, going back to the late 1980s. In both product chains this started with single initiatives, originating from civil society, taking a market oriented approach and connecting to some of the producers. In their first years these systems were successful in small niches of these markets. Comparable initiatives have been taken in Europe and North America simultaneously.

Both in the timber and coffee chains this has resulted in responses in the market and the emergence of competing systems. These 'responding' systems come from other segments of the same product markets and in the case of timber from producer country governments in cooperation with responding firms in other (larger) market segments in the timber markets.

This 'initiation-response' sequence has resulted in variation in systems, both between countries, in the stringency levels set in the criteria applied and in the inclusiveness of the various dimensions related to the concept of sustainable development. We will first discuss these developments and then report on the effects in these markets in The Netherlands.

\subsection{Developments in the Timber Supply Chain}

Certification of timber sourced from developing countries has a relatively long history. Private and public initiatives have emerged and resulted in adaptations in public and private certification practices over time.

The Forest Stewardship Council (FSC) was created in reaction to the slowness and inability of domestic and international governmental responses (e.g. ITTO, UNCED) as well as boycott campaigns to forest related problems. 'FSC and its supporters turned to the marketplace to generate incentives for forest businesses to conform to environmentally and socially responsible forest practices' (Cashore et al., 2006, p. 7). Their first meeting was held in 1990 by of a group of timber users, traders, and representatives of environmental and human-rights organisations in California, USA. FSC was officially established in 1993 with the objective of addressing unsustainable forest management in the tropics.

In reaction to the emergence of an increasing number of timber certification systems abroad, a second type of certification system in The Netherlands appeared to certify already existing systems. At this point, the objective of the Dutch Government was to define what sustainable forest management is and to provide clarity in terms of the various existing forest management labels and their standards (Assessment Criteria Tropical Timber). To be able to assess every timber certification scheme against this minimum requirement, the business sector established the Keurhout Foundation (Stichting Keurhout) in 1996, supported by the former Ministry of Agriculture, Nature and Food (LNV) and the former Ministry of Housing, Spatial Planning and the Environment (VROM). The establishment of the Keurhout certificate met resistance from the FSC, which was at that time perceived as the only sustainable timber certification scheme. The Keurhout system was labelled as ineffective in a formal evaluation conducted in 2001 on behalf of the Dutch Ministry of Agriculture (LNV) and was then terminated (KPMG, 2001).

Meanwhile another, comparable initiative, the Programme for the Endorsement of Forest Certification (PEFC) was launched in 1999 in Paris by representatives of eleven officially constituted national PEFC governing bodies, mainly formed by landowners and industry under the name 'Pan European Forest Certificate'. It was conceived as a European umbrella organisation with mandate to evaluate and endorse national standards for sustainable forest management. The establishment of PEFC is said to be a counter reaction to FSC (Cashore et al., 2006). When FSC national standards were being established in countries like Finland and Sweden, there was strong resistance from small, farm-forestry operators concerned with the protection of private property rights and with minimising costs (Cashore et al., 2006). The first national schemes were endorsed by the PEFC in 2000. Today, the PEFC scheme covers national forest standards from all over the world.

The first noticeable difference between the PEFC and FSC is the different standards they refer to in determining the sustainability of 
forest management. FSC has its own principles and indicators that expand beyond national regulation, while PEFC refers to guidelines developed at the inter-governmental level, thus taking government regulation as baseline. Both systems are private, yet FSC develops its own regulation and criteria, while PEFC relies on criteria developed earlier by governments.

Despite the long history and the original ambition of FSC to improve the use of tropical forest protection, the majority of FSC and PEFC certified forests are located in the Western countries. In 2009, $19 \%$ of FSC certified forests were situated in developing and transition countries, which account for 44 countries. Only 13\% of FSC certified forests are said to be tropical forests (AidEnvironment, 2008; FSC, 2009; PEFC, 2009).

PEFC on the other hand was initiated to protect European forests, but has also been extended to forests located outside Europe. Still, only $1.25 \%$ of PEFC certified forests are located in developing countries; more specifically in Chile and Brazil (PEFC, 2009).

The first indicator for measuring the success of certified products is their market share, such as for sustainable timber products. This requires looking at both trade flows (exports/imports) and at sales in the different relevant product markets (including construction materials, finished products, paper etc.). Systematic monitoring of these trade impacts (in time and over categories) is not available. Both FSC and PEFC do not provide such detailed statistics. Some data is available from other sources, giving an incomplete picture, but allowing us to sketch the main trends.

Here we have to distinguish between the use of timber for paper production or as any form of timber product. In 2005 the market for FSC certified paper was very small $(0.5 \%)$, while no PEFC certified paper was yet available. In two years the combined share grew to 6\% (2.8\% FSC and 3.2\% PEFC), while a further growth to 9\% in 2011 is expected (Oldenburger et al., 2010: 35-37).

The market share of sustainably produced timber is far larger and strongly increasing, but for tropical timber it is still very limited (PBL, 2009). If we look at the total sum of the various sources, we see that a strong development has taken place over the last few years. This justifies us to state that we are entering a phase of market breakthrough of sustainable timber. Fig. 2 shows the developments based on the data available.

In 2005, 13.3\% of timber sold on the Dutch market was certified (FSC, PEFC, MTCC, CSA, SFI and the rest certified by Keurhout) (see Fig. 2) (Oldenburger and Leek, 2006), of which FSC certified timber accounted for $9.3 \%$ and PEFC for $3.9 \%$. These numbers have grown to $11.6 \%$ and $22.1 \%$ in 2008 , summing up to $33.8 \%$ of the market.

But these numbers don't show the full picture. An important amount of timber that is available in the Dutch market has been produced in certified forests, even when it does not bear any label or certification. Timber without any certification, but sourced from certified forests, is estimated to be around $23.1 \%$ in 2005 and $13.4 \%$ in 2008. In this category, PEFC's share is relatively large, $18 \%$, compared to FSC, 2.9\%, both in 2008 (Oldenburger et al., 2010).

Combining these data, we see a growth in total market share for products from various certified sustainable sources, from $36.4 \%$ in 2005 to $47.3 \%$ in 2008 .

\subsection{Developments in the Coffee Supply Chain}

In the last two decades, various market and civil society initiatives to make the production and trade of coffee more sustainable, have also emerged. For this study we have selected the five main private voluntary certification schemes available for coffee (nowadays also including products like cocoa and tea). These systems are Organic, Fairtrade, Rainforest Alliance, GlobalGAP, and UtZ Certified. All of these schemes, except GlobalGAP, use a consumer label on the final product, which is aimed at influencing consumers' perception and choices. The origin, scope and principles of these systems differ from one to another.

Organic is the oldest certification system and the only scheme regulated under national and European laws. The organic schemes were originally aimed at changing the production processes in the Western countries and it was only until a later stage that they were also used on imported products from developing countries. The Fairtrade, Rainforest Alliance, and UtZ Certified schemes, on the other hand, are exclusively aiming at imported products from developing countries.

The latter three systems have been developed by private stakeholders in Western countries, sometimes in consultation with Southern partners and producers: Fairtrade and UtZ were initiated in The Netherlands, and Rainforest Alliance in the United States. Fairtrade and Rainforest Alliance are both initiated by civil society organisations, whereas UtZ Certified is the initiative of a retailer: the Ahold Coffee Company. Today, UtZ Certified is a foundation involving actors from different sectors.

All the certification systems studied here, except Organic and GlobalGAP, began their activities with the certification of one particular product and later expanded to other products. Max Havelaar (Fairtrade Netherlands) and UtZ, for example, began certifying coffee, while the Rainforest Alliance started certifying tropical timber. The GlobalGAP and Organic systems, however, originated to promote a broader adoption of more environmentally friendly agricultural production methods in general. They have developed standards for

Sustainable wood consumption in the Netherlands

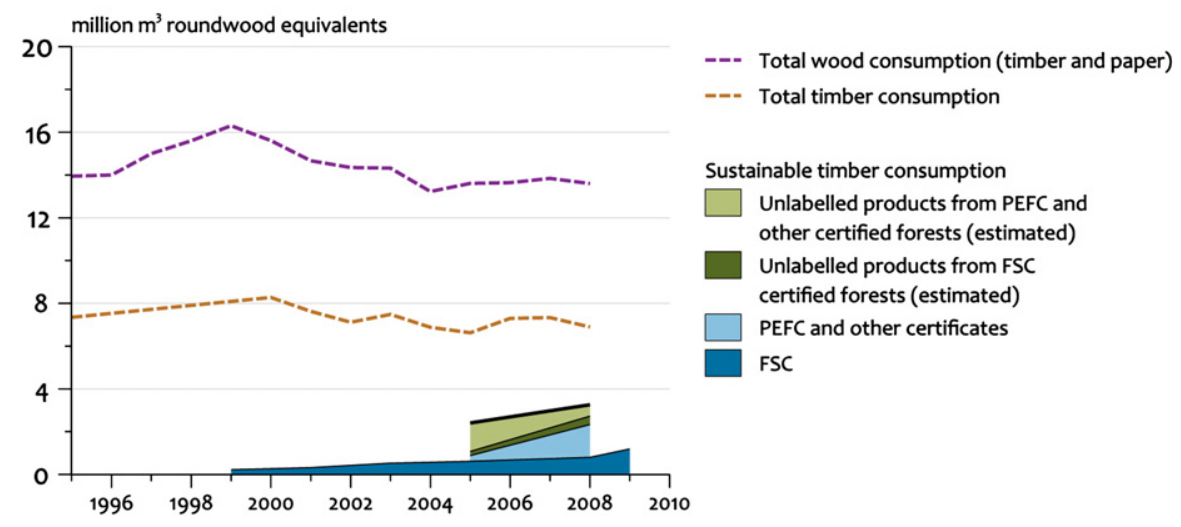

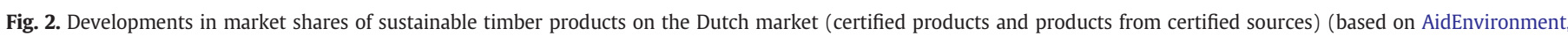
2008; Oldenburger et al., 2010). 
different product groups, ranging from plant and livestock production to plant propagation materials and compound feed manufacturing.

The standards developed by Organic, Rainforest Alliance, and GlobalGAP are based on different approaches towards protecting the environment in agricultural production. Organic food is grown and processed without using synthetic fertilisers or pesticides; livestock feed additives, and genetically modified organisms. The standards of the Rainforest Alliance require, among other things, compliance with internationally recognised Integrated Pest Management (IPM) practices. IPM takes advantage of every available pest management option and makes judicious use of pesticides. The concept of Good Agricultural Practices (GAP) relies on improved agricultural methods, such as fertiliser and pest management, which contribute to food quality, safety, and security.

When it comes to UtZ Certified and Fairtrade, there has been a lot of discussion about the differences in their approach (for a more thorough revision of this discussion see a positioning on document http:// www.Utzcertified.org/index.php?pageID=111). Max Havelaar (Fairtrade) was created with the clear developmental objective of helping small producers to access world markets and to improve their livelihoods. It aims at up scaling the production of sustainable agrocommodities and at enabling brands to incorporate and demonstrate responsibility in their entire product chain.

Moreover, each of the five certification systems reviewed here, has a different approach to sustainability; while some put more emphasis on labour conditions for workers, others place it on biodiversity protection or on the application of better agricultural practices. These fundamental differences between the systems' approach imply also some differences with regard to the stringency of the systems' standards. It is often pointed out that the Fairtrade and Organic systems are stricter, since they aim to create alternative trading models, while UtZ Certified, Rainforest Alliance, and GlobalGAP work to improve existing practices and structures and should be regarded primarily as a tool for companies. The Fairtrade and Organic systems, on the other hand, strongly rely on committed consumers who make a deliberate choice for products that contribute to social and environmental improvements in the South and that are willing to pay a premium price that producers can invest in development. GlobalGAP, UtZ Certified, and the Rainforest Alliance to a much lesser extent, are based on the premise that it is the duty of brands to inform consumers where their product was produced and how. Since their systems are based on existing market structures and supply and demand, they do not offer guaranteed minimum prices or premiums.

It should be noted however that a comparison of systems should reflect the regular adaptations in the certification schemes. In recent years many of these systems have implemented new version, often expanding their scopes, thus reducing the differences between their approaches (see also Vermeulen and Metselaar, forthcoming; Davies, 2007)

If we want to assess the demand side effectiveness; we face the same information problem as discussed with timber: various sources give small pieces of the full picture, but systematic market data are not available. In terms of market shares the world market for certified coffee continues to grow: from 2002 to 2008 the world market share of certified coffee grew from $1 \%$ to $6 \%$ (TCC, 2009).

Fig. 3 summarises the key facts from various data sources for the Dutch market. The market shares of both Organic and Fairtrade coffee on the Dutch market remained stable over the recent years (TCC, 2009). In 2008, about 25\% of coffee in the Dutch market was estimated to be certified (Fairtrade, Organic, Rainforest Alliance, UtZ Certified, 4C, C.A.F.E., and AAA) (TCC, 2009).

This is very high compared to surrounding countries. The market share of Organic coffee in Germany in 2008 was $2 \%$, while the amount of Fairtrade coffee sold in Germany was $1 \%$, half of which was double certified (also organic). About 5\% of coffee on the German market is certified with any of the various certificates on the market (TCC, 2009, p. 13).

Fig. 3 also shows another part of the story: just like with timber not all coffee from certified sources ends as certified coffee on the shelves. Data on this justifies an estimation of an additional market share for unlabelled coffee sources from various certified growers (TCC, 2009), implying that markets are ahead of consumer demand for certified products. In addition to the $25-29 \%$ certified coffee another $15-20 \%$ coffee from certified grower has come to the market, summing up to approximately $45 \%$ in 2008 . Recent data provided to us by Max Havelaar and UtZ Certified show that the total market share of certified coffee on the Dutch market has strongly grown to $50 \%$ in 2009 , indicating that this original over-supply of coffee from certified growers, now has found its way to coffee being sold as certified on the consumer market.

\subsection{Case Comparison: Variation and Evolution}

Comparing the timber and coffee chains, we see a pattern of variation and evolution. Both the original private certification systems and the 'responding' systems aim to assure compliance by producers in developing countries to at least the internationally agreed levels of regulation in the fields of environmental and social policies. The original fair trade and organic certification intend to go even (further) beyond these compliance levels, adopting organic production techniques and/or different models of trade pricing.

Sustainable coffee consumption in the Netherlands

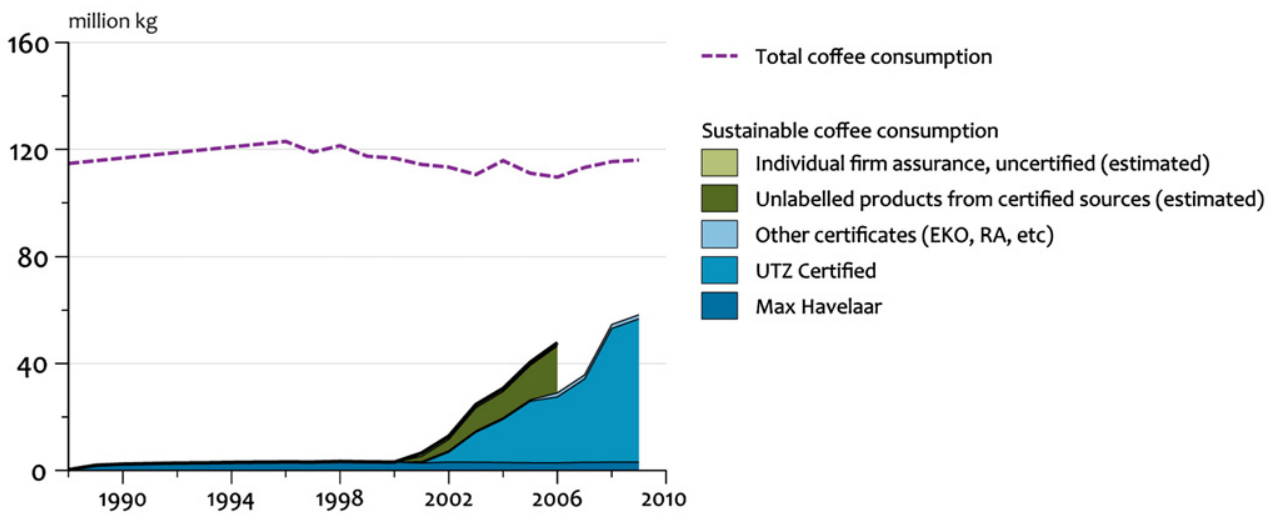

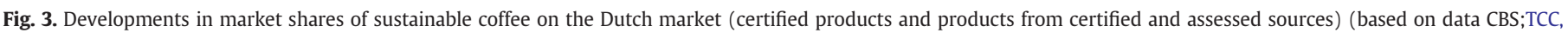
2009; data Max Havelaar). 
Looking at the two selected product chains we also observe that both in the timber and coffee chains the experiences created by earlier pioneer systems (FSC, Rainforest Alliance, Fair Trade, GlobalGAP, and UtZ Certified) have been used to take the approach to other product groups, often closely related and still comparable (like bananas, cocoa and tea).

All of the systems analysed have furthermore in common that they are run by fairly lean organisations, with very limited numbers of employees and limited operational costs while still covering large numbers of countries both at the supply side and at the demand side (FSC, 2009; PEFC, 2009). Both UtZ Certified and GlobalGAP have been able to achieve fairly worldwide coverage (over 100 countries) in less than 5 years (GLOBALGAP, 2009; UtZ Certified, 2010).

Another observation in this respect is that the private certification systems studied here in the last years increasingly have become 'allinclusive'. Originally the early systems all had a specific focus, focussing either at environmental issues or at social issues. The 'responding' systems have emerged in a context of single issues, public unrest and anti-business campaigning (mad cow disease, Asian flu, child labour in cacao, etc.). In this context, the initiators have taken a pro-active approach, trying to organise supply chain management in such a way that unexpected new 'single issue' conflicts can be prevented or at least accommodated. Thus, all these 'responding' systems from the start have integrated the environmental and social-ethical issues into their system and connected it to aspects of traceability and compliance. The initial private certification systems have in turn responded by expanding their originally more narrow scope (either organic or social-ethically oriented) towards more inclusive criteria sets.

Looking at this rapid development from the perspective of policy sciences, three observations stand out. First, implementation in the private policy cycle shows to be a fairly fast one, showing design, decision-making and worldwide implementation to happen in a few years. Second, where governments tend to struggle with policy integration, sustainable supply chain governance systems are successful in integrating the complex wide spectrum of sustainability issues into one 'all inclusive' instrument. The complexity of this integration should not be underestimated: individual suppliers are facing more than 900 specific requirements (see Muller et al., 2009). Third, although we do present the private governance systems as strong form of self-regulation, we need to stress that this does not take the form of 'self-regulation in isolation'. Or in other words, selfregulation does not replace the other modes of governance. In practice, 'coalitions of the willing' (front running firms together with NGOs) take the initiative, and simply effectively translate the exiting global consensus on various issues available in soft supranational laws, treaties and programmes, into easily applicable business-tobusiness criteria (see also Smith and Fischlein, 2010).

With the recent data on market breakthrough of these 'first mover' supply chains, we see that shortly after competition between multiple private certification schemes is occurring, an impressive shift in the market takes place in The Netherlands (47\% for timber, $50 \%$ for coffee). Growing market shares are also reported for various product chains in other countries (Potts et al., 2010). A key question is how governments can attribute this to the multi actor dynamics in these self-regulating product markets.

\section{Government Roles in the Development and Implementation Stages}

This brings us to the main question in this article: which strategies and instruments do governments in these self-governing dynamic apply and how can their effectiveness be evaluated? The positions of governments in SSCG systems differ from the traditional position of government, normally having the lead in pursuing public goals. This study addresses the situation in which private actors (target groups of traditional government policies) acting as frontrunners in relevant product chains, themselves initiate solutions to address public problems. Governments are hardly in the position to resume their traditional regulating role in global supply chains, but may try to support and accelerate desired activities as one of the members of such networks of actors. But also in this situation, governments remain responsible for public goals. So, we are also interested in the implications for governments in fulfilling their public responsibilities in this self-governance situation.

We make a distinction between roles taken on by governments in the early stage of development of private certification systems and the stage of operating and implementation certification systems. As described in Section 3 our research focussed on creating a full inventory of policy instruments applied in connection to the two product chains in study, over the period of the existence of the described certification systems. Looking at the roles taken on in practice, we can in general best summarise the role of governments as 'side line support' in combination with 'using market power' as major institutional consumer (public sustainable procurement).

\subsection{Development Stage}

The review of the development stage of the SSCG systems in both cases identified 9 different policy instruments or activities used by governments (we only give very short descriptions, given the limited space in this article, more details are provided in the full research report (Vermeulen et al., 2010) available online www.pbl.nl/en/ publications/2010). Only one of these instruments was used both in the timber and coffee chains: defining minimum standards. This refers to the EU rules for organic farming and national rules for sustainable forestry.

The private initiatives discussed in Section 3 are each linked in a specific way to various types of government activity: FSC emerged as a reaction to the slowness of intergovernmental processes, while PEFC was built up using criteria developed in such intergovernmental processes, responding years later to the existence of the privately developed FSC. PEFC as a mainstream market initiative is closely linked to government activities, as it evaluates and endorses national certifications that already exist, such as the Canadian Standards Association (CSA).

Our interviews have shown that especially in the stage of initiating the systems studied, the role of governments has been very limited. All certification initiatives were established independently by private actors, sometimes rather despite adversarial government activity or at best with limited support from political opinion makers expressing moral encouragements (timber and coffee) or fairly small financial support in this stage. In the case of timber, the Dutch government launched its policy programme starting in 1991, in the case of sustainable coffee no specific government policy existed during the development of both Max Havelaar and UtZ Certified.

The level of government involvement and support during this development stage is quite different for the various systems: FSC was more or less supported by policy makers by communicating their political support in the 1990s (after its creation), while the government involvement in the initiation of the competing system Keurhout has been far more active with financial support and resulted from collaborative activities with the timber supply chain working towards a covenant on tropical timber.

For the case of the coffee chain, there has not been any role of governments in the development stage of the Rainforest Alliance and GlobalGAP certification systems. Rainforest Alliance was initiated in the USA and has never received direct financial support from this or any other government. GlobalGAP was initiated by Dutch and other European retailers along with farmer unions and importers, which jointly developed a harmonised approach to safety and health requirements for imported food. GlobalGAP was inspired by other 
existing certification systems, like organic and meat traceability initiatives, but was from the start entirely privately driven. However, some of the coffee related systems did indirectly receive small amounts of government support, in the form of financial means granted by development NGOs, who in their turn received part of their budget from the Ministry of Foreign Affairs.

All the identified instruments have been summarised in Table 1, expressing the general observation that governments were involved from the sidelines during the creation of these certification systems by private actors. The table also indicates which ministry applied which instruments.

\subsection{Implementation Stage}

The implementation and management of a certification system may be more complex than its development stage. Private actors in the supply chain in their daily routines engage in supplying and purchasing certified products, in their promotion, and their consolidation in national and international markets. Implementation of this type of self-regulation instruments implies that the certifying organisations and the third parties for auditing assure the effective functioning of the certification system. The key question here is what roles governments have taken in enabling this.

Governments were found to be more active during the implementation stage of private voluntary certification systems, especially as they began to regard these systems as tools for international development, environmental protection, and market transformation. We identified the application of 15 different instruments in the timber case and 11 different instruments in the coffee case in The Netherlands throughout the period studied. These instruments are directed either at actors at the Dutch side of the supply chain, or at actor in the supplying developing countries. In both cases we see instruments fitting in each of the 4 strategies distinguished in Section 3.

At the Dutch demand side some forms of traditional regulation are applied (regulation on organic certification, bilateral product import inspection agreements) or have more recently being discussed (traceability obligations for importers). Third parties are addressed with interactive policies aiming for voluntary agreements on selling and purchasing certified products or voluntarily applying corporate social responsibility policies (including supply chain management).
However most activities found are forms of financial or promotional support to the systems themselves and directed to the supply side actors: supporting small farmers in developing countries to participate. International development policies play a strong role in this, selectively promoting the systems linking to smallholder support in developing countries.

The third strategy, 'facilitating self-regulation' has recently strongly been elaborated in The Netherlands. The Dutch government has financially enabled the creation of the Sustainable Trade Initiative (IDH) since 2008, an independent tripartite (market, government, and civil society) organisation. In this way a more active facilitation role is taken up, with a stronger emphasis on initiating and facilitating cooperation between the main stakeholders of selected product chains, with the ambition to mainstream private sustainable supply chain certification.

The fourth strategy, applying selectiveness in government's public procurement has been applied starting in the mid 1990s, but in The Netherlands has been reinforced by making sustainability standard obligatory since 2009. Specific requirements have been developed for a large list of product groups, including timber and coffee.

All instruments as used by the various ministries are summarised in Table 2, expressing the general line of governments playing a supportive role in the market place. Presented between brackets are the recently discussed new instruments, yet to be effectuated. In the timber case, the dominant mixture is that of the traditional Strategies 1, 3 and 4, while in the case of coffee the emphasis is on Strategies 3 and 4.

\subsection{Policy Integration}

Addressing sustainability in international supply chains links to various different tiers and sectors of government activity. In practice an explicit integrated policy for sustainable products sourced from developing countries has not been developed. But policies have been developed in the various relevant governmental departments to address specific aspects as part of other separate policy agendas. The Biodiversity Policy programme of the (former) Ministry of Agriculture, Nature and Food Safety (LNV) has had a leading role in this. Their focus has been on sustainable food production, both domestic, European and in the global context, linking it to food safety and traceability and biodiversity. Second most active has been Foreign Affairs with its international development assistance programmes. They tend to stress

Table 1

Inventory of instruments applied in practice in the development stage of systems in the timber and coffee chains.

\begin{tabular}{|c|c|c|}
\hline \multirow[t]{2}{*}{ Instrument category } & \multicolumn{2}{|l|}{ Instrument examples } \\
\hline & Tropical timber & Coffee \\
\hline \multicolumn{3}{|c|}{ Strategy 1: classical central regulation by means of coercion and incentives } \\
\hline 1A Direct regulation & $\begin{array}{l}\text { - Intergovernmental processes to define criteria }{ }^{\mathrm{I}} \\
\text { - Defining minimum standards }{ }^{\mathrm{I}}\end{array}$ & - Defining minimum standards $\mathrm{s}^{\mathrm{I} / \mathrm{EU}}$ \\
\hline \multicolumn{3}{|l|}{ 1B Economic incentives } \\
\hline 1C General communication & - Communicating political support ${ }^{\mathrm{I}}$ & - Expressing views on corporate responsibilities ${ }^{\mathrm{III} / \mathrm{IV}}$ \\
\hline \multicolumn{3}{|c|}{ Strategy 2: interactive regulation and internalisation } \\
\hline 2A Cooperation with target groups & $\begin{array}{l}\text { - Covenant Tropical Timber }(1993)^{\mathrm{I}} \\
\text { - Development of } 2 \text { nd system }\end{array}$ & \\
\hline \multicolumn{3}{|l|}{ 2B Financing cooperative programmes } \\
\hline \multicolumn{3}{|l|}{ Strategy 3: facilitating self-regulation } \\
\hline 3B Economic incentives & - Direct financial support for initial studies ${ }^{I}$ & $\begin{array}{l}\text { - Minor direct financial support } \\
\text { - Indirect funding through } \mathrm{NGO}^{\mathrm{II}}\end{array}$ \\
\hline 3C General communication & & - Positive recognition of a particular system ${ }^{\mathrm{II}}$ \\
\hline \multicolumn{3}{|l|}{ 3D Network creation } \\
\hline $\begin{array}{l}\text { Strategy 4: government as active con } \\
\text { 4A Selective public procurement }\end{array}$ & place & \\
\hline
\end{tabular}

Ministry applying an instrument: I, Agriculture; II, Foreign Affairs; III, Economic Affairs; IV, Environment; V, Finance. 
Table 2

Inventory of instruments applied in practice in the implementation stage of systems in the timber and coffee chains.

\begin{tabular}{|c|c|c|}
\hline \multirow[t]{2}{*}{ Instrument category } & \multicolumn{2}{|l|}{ Instrument examples } \\
\hline & Tropical timber & Coffee \\
\hline \multicolumn{3}{|c|}{ Strategy 1: classical central regulation by means of coercion and incentives } \\
\hline 1A Direct regulation & $\begin{array}{l}\text { - Bilateral product import inspection agreements//I/EU }\left(\text { prosecution of importers of illegal timber) }{ }^{1 / I I}\right. \\
\text { - Import restrictions for illegally sourced timber }{ }^{1 / / I} \text { (setting traceability and legality obligations for timber importers) }{ }^{1 / I I}\end{array}$ & \\
\hline \multirow{2}{*}{\multicolumn{3}{|c|}{ - Applying special tax arrangements for standard organisation ${ }^{\mathrm{V}}$}} \\
\hline & & \\
\hline \multicolumn{3}{|c|}{ Strategy 2: interactive regulation and internalisation } \\
\hline \multicolumn{2}{|c|}{ 2A Cooperation with target groups } & \multirow{2}{*}{ - Promotion of voluntary CSR ${ }^{\mathrm{II} / \mathrm{II}}$} \\
\hline 2B Financing cooperative programmes & - Financing cooperative action plans or campaigns ${ }^{\mathrm{I} / \mathrm{II}}$ & \\
\hline \multicolumn{3}{|l|}{ Strategy 3: facilitating self-regulation } \\
\hline \multicolumn{3}{|l|}{$3 \mathrm{~A}$ Indirect regulation } \\
\hline \multirow[t]{2}{*}{ 3B Economic incentives } & - Applying special tax arrangements ${ }^{\mathrm{V}}$ & - Voluntary agreements on product supply in retail ${ }^{\mathrm{IV}}$ \\
\hline & $\begin{array}{l}\text { - Financing activities related to implementation" } \\
\text { - Indirect funding through NGOS" }\end{array}$ & $\begin{array}{l}\text { - Financing activities related to implementation } \\
\text { - Indirect funding through } \mathrm{NGO}^{\mathrm{II}} \\
\text { - Support critical consumer } \mathrm{NGOs}^{\mathrm{II} / \mathrm{IV}}\end{array}$ \\
\hline \multirow[t]{2}{*}{ 3C General communication } & - Promoting consumer awareness ${ }^{\mathrm{IV}}$ & - Declaring political support for actors in the market game $\mathrm{I}^{\mathrm{I} / \mathrm{I} / \mathrm{III} / \mathrm{IV}}$ \\
\hline & - Financing monitoring of the market ${ }^{1 / \mathrm{V}}$ & - Promoting consumer awareness ${ }^{\mathrm{IV}}$ \\
\hline 3D Network creation & - Creation of new actors in the playing field ${ }^{1 / I}$ & - Creation of new actors in the playing field ${ }^{1 / I}$ \\
\hline \multicolumn{3}{|c|}{ Strategy 4: government as active consumer in the market place } \\
\hline \multirow[t]{3}{*}{ 4A Selective public procurement } & - Definition of own minimum requirements ${ }^{\mathrm{IV}}$ & - Definition of own minimum requirements ${ }^{\mathrm{VV}}$ \\
\hline & - Voluntary public procurement programmes $\mathrm{s}^{\mathrm{IV}}$ & - Voluntary public procurement programmes ${ }^{\mathrm{IV}}$ \\
\hline & - Formal regulation of public procurement decisions $\mathrm{I}^{\mathrm{IV}}$ & - Formal regulation of public procurement decisions ${ }^{\mathrm{IV}}$ \\
\hline
\end{tabular}


economic development and poverty reduction, linkages to achieving the Millennium Development Goals, thus focussing on the social dimension of sustainable development and socio-economic empowerment in developing countries. From this perspective they tended to prefer the Fair Trade system rather than the other systems.

On the other hand we see the former Ministry of Environment (VROM) with its focus on various environmental impacts, but being mainly active in the national context and with only weak strategies on remote impacts. They have, same like the Ministry of Economic Affairs, linked the issue of external impacts of domestic consumption to the policy agenda of voluntary corporate social responsibility (CSR). Apart from this the topic is linked to some of their policy foci, like: climate change and the energy transition; resources and biodiversity transition and the mobility transition. Some of the projects in these programmes supply chain optimisation. Finally, the Ministry of Economic Affairs, also in its responsibility for international trade policy, has programmes on promoting CSR in global trade, on supporting businesses active in international trade and is responsible for the inputs in inter-governmental agenda for trade policies (non tariff barrier issues).

In our interviews policymakers of these departments indicated that some interdepartmental deliberations take place about each other's programmes, but an explicit integrated policy for sustainable products sourced from developing countries does not exist. As a result some departments selectively support some of the competing certification systems, while other departments support all of them.

\section{Conclusions: Strengths and Weaknesses of Self-regulated Markets}

In the previous section we concluded that we could speak in terms of maturing sustainable supply chains, especially after variation and evolution of certification systems in this product chain occur in importing countries. Examples of mainstreaming up to $47-50 \%$ market shares are now available for timber and coffee. In addition, the efficient and lean organisation of the various certification systems can be labelled as strength, if we compare this to government agencies.

Governments are increasingly recognising this potential. Having made this observation about the potentials of private certification, we also need to recognise the weaknesses of self-governance in international product supply chains.

\subsection{Confusion for Consumers}

In each product chain we see variation and competition between voluntary certification systems (those merely ensuring legal compliance versus systems going far beyond legal requirements). Such variation and competition are generally considered positive by stakeholders, although the downside maybe that it creates confusion for consumers. Confusion may also result in the reduced credibility of certification systems and reduced consumer commitment. This brings some government agencies to more selective approaches, as described for Fairtrade in the United Kingdom.

\subsection{Confusion for Producers}

The same variation and competition also cause confusion on the supply side. Farmers and producers in developing countries are confronted with growing numbers of certification systems and additional business-to-business supply chain requirements. This confusion is caused both by the variations in levels of strictness and aspect inclusiveness and by the fact that they may work with supply chain partners from many different countries. This is especially relevant to small-scale producers.

\subsection{Organising Harmonisation}

Here the issue is whether or not to reduce this variation through harmonisation, coordination and/or cooperation. If desirable, the key question is still whether this would be a role for the voluntary private certification systems themselves (with ISEAL already doing this) or whether it would be an appropriate role for national governments or for example the European Union or UN bodies. Defining minimum environmental and socio-ethical requirements and organisational requirements would be the next step. This would make sense if private certification were connected to specific government policies (see later).

However, harmonisation may very well conflict with enhanced competition which, as we concluded, may very well be seen as one of the major triggering factors in the mainstream breakthrough we now see. Taking this in consideration, harmonisation should rather be restricted to procedural harmonisation (in the way ISEAL is offering) rather than content harmonisation (reducing variation and thus competition).

\subsection{Lack of Transparency, Monitoring and Evaluation}

With multiple competing private certification systems active, information about performance in the market and the supply side (environmental benefits, economic and community impacts) is very poorly available. Information on the full impacts is also further obscured because of the variation in sustainable supply chain management strategies, not all of which results in product based certificates visible for consumers, with single firm approaches and business-tobusiness approaches such as GlobalGAP as examples.

No single relevant actor is responsible for the full picture. In the situation of self-governance, it is unclear who will take this common responsibility. This might be a task either for cooperating actors in the market or for government agencies. Independent of the choice made here, governments, due to their public task, should ultimately have a role in measuring the level of public goal attainment, also if selfgovernance in the market is supported.

\subsection{Selectiveness in Prioritising Product Chains}

Businesses in self-regulating markets and non-governmental organisations start working towards certification systems when they feel the need to do so. The first emergence of private certification has taken place mainly in the food and agro-products sector, in response to consumer pressure (health and safety issues), and based on previous experience in meeting traceability requirements. Looking both at environmental impacts and socio-ethical aspects, other product groups may very well be relevant in terms of improving sustainable supply chain governance but may lack the consumer pressure connected to food products that is required to trigger producer activity. An example is mineral mining.

The question as to what extent these weaknesses in self-regulating markets affect the potential success of private certification is achieving sustainability goals. Hard statements are difficult to give, but the expectation is that these limitations will ultimately result in reducing potential impacts if not properly taken into account in future developments. The challenge here is to determine how combined and complementary strategies of the various key stakeholders active in this complex international market and society system can accelerate the breakthrough of sustainable products. This is shortly addressed in the next section, from the perspective of governments, the core actor this study focuses on.

\section{Policy Implications: Coherent Strategies for a Sustainable Footprint Policy}

In this paper we have analysed the dynamics in two groups of supply chains, with the longest history of full implementation of private 
certification and looked in detail at the role governments have played in these product markets. In our conclusions we observe increasing competition in the timber and coffee markets and strong growth of market shares of certified sustainable products. In these cases we can start to talk in terms of 'maturing' sustainable supply chains, after a long initial period of sustainability being restricted to small niche markets.

Self-governance implemented by actors in the market and civil society has the potential of creating effective and efficient solutions to the regulatory vacuum that governments are facing in the context of international trade. However, we identified various limitations and argued that some essential functions of public policy tend to fall between two stools. Thus it requires an explicit government strategy and organisation. Governments have a specific role: taking responsibility for the production of public goods (Kok et al., 2011). In the field of ensuring sustainable production in global supply chains non-state actors have taken a leading role and governments reconsider their position. The self-regulating mechanism described in this article can be supported by national governments in various forms. In any case governments continue addressing public goals, like enhancing sustainable development, both 'here' and 'there' and 'for now' and 'in the future'.

Governments may very well strategically decide to allow selfregulating markets to take the lead, but they still need to include the following key elements of good 'meta' governance:

- independent problem analysis that is also politically supported;

- a resulting long-term vision and goal setting;

- explicit positioning in societal dynamics (the market game), thus resulting in the articulation of its role by means of:

o suitable strategy and instruments;

o enabling learning processes;

o creating transparency for actors in the game.

- continued linking of self-regulating markets to existing bottom line regulation in the fields of environment, health and social development;

- organising the monitoring of goal achievement and goal attainment evaluation (feedback).

These roles are essential, irrespective of the strategic choice to be made regarding how to address self-regulating markets as a government. Various stakeholders interviewed for this study referred to the absence of an integrated, coherent policy strategy, with various ministries each stressing different main goals and making different choices in applying instruments. They suggested two opposite directions for such an integrated policy: either returning to a stronger role of governments or supporting stronger self-regulation. ${ }^{1}$

The main choices to be made are on whether or not to support a variety of competing certification systems, whether or not to regulate certification (or the performance of certification and auditing agencies), and whether to organise the monitoring of goal attainment and feedback in the public sector or in the private sector. Choices need to be made on how to address both front-running firms and laggards. Most essential however is that the various government agencies work as one government 'hand', using the same integrated policy choice on its position in the complex playing field of global supply chain.

\section{Discussion and Research Implications}

In this study we illustrated that in the context of self-regulation, the government's role of protecting public goods is shared with private actors. The analysis not only shows recognition by government agencies of the merits of self-regulating markets for (globally

\footnotetext{
${ }^{1}$ We have elaborated three coherent sets of instruments for each direction. See Vermeulen et al. (2010).
}

sourced) sustainable products, but also illustrates the weak coordination and integration. This can in principle be seen as a key feature of multi-actor governance situations, especially when business actors, civil society and government agency, independently and simultaneously can initiate new approaches. This requires further integration and collaboration of various relevant academic disciplines. We presented a research approach combining concepts from the fields of environmental business management, supply chain management and from policy science.

We showed that increased competition has led to successful mainstreaming, but by its nature creates various dilemmas: between competition and coordination, between virtues of variation and the need for harmonisation. The dynamics in this field can be described as parallel 'public policy cycles' and 'private policy cycles', which are not well linked. Governments are, as agents with many different hands, playing at a very complex playing field, populated with competing groups of firms, each with diverse linkages with supply chain partners and NGOs and addressing different segments in consumer markets. Both in the public and in the private 'arena' diverse instruments and approaches are applied, all of which call for systematic academic analysis of the key conditions determining their effectiveness. With this approach we added an additional perspective to some more comprehensive research approaches in this field (Auld, 2010; Coe et al., 2004; Erol et al., 2011; Gereffi et al., 2005; Vermeulen, 2010). We observed that, more or less as a result of the distributed responsibilities, none of the actors takes a coordinating role. Also research on the performance of these sustainable supply chain governance systems, creating both the intended economic, environmental and socio-ethical impacts is not well organised. Here we see a collaborative assignment for scholars in related disciplines. Our framework of four complementary strategies and connected public and private policy cycles can be applied.

\section{Acknowledgements}

The authors thank M. van Oorschot. J. Metselaar, Y. Uitenboogaart, L.D.L. Pesqueira and two anonymous reviewers for their contributions and comments.

\section{References}

Aidenvironment, 2008. FSC hout in de Nederlandse Markt 2007: De beschikbaarheid van FSC-gecertificeerd hout op de Nederlands markt in 2007 (FSC Timber on the Dutch Market 2007). . Amsterdam.

Albersmeier, F., Schulze, H., Spiller, A., 2009. Evaluation and reliability of the organic certification system: perceptions by farmers in Latin America. Sustainable Development 17 (5), 311-324.

Alvarez, G., Pilbeam, C., Wilding, R., 2010. Nestlé Nespresso AAA sustainable quality program: an investigation into the governance dynamics in a multi-stakeholder supply chain network. Supply Chain Management: An International Journal 15 (2), 165-182.

Andrews, R., 1998. Environmental regulation and business self-regulation. Policy Sciences 31 (3), 177-197.

Arce, A., 2009. Living in times of solidarity: fair trade and the fractured life worlds of Guatemalan coffee farmers. Journal of International Development 21 (7), 1031-1041.

Auld, G., 2010. Assessing certification as governance: effects and broader consequences for coffee. The Journal of Environment and Development 19 (2), 215-241.

Barrientos, S., 2007. Do workers benefit from ethical trade? Assessing codes of labour practice in global production systems. Third World Quarterly 28 (4), 713-729 (June 2007).

Bitzer, V., Francken, M., Glasbergen, P., 2008. Intersectoral partnerships for a sustainable coffee chain: really addressing sustainability or just picking (coffee) cherries? Global Environmental Change 18 (2), 271-284.

Blowfield, M., 2003. Ethical supply chains in the cocoa, coffee and tea industries. Greener Management International 15-24.

Bressers, J.T.A., Klok, P.-J., 1987. Grondslagen voor een instrumententheorie (Fundamentals of a instrument theorie). Beleidswetenschap 1 (1), 77-97.

Bush, S., Khiem, N., Sinh, L.X., 2009. Governing the Environmental and social dimensions of Pangasius production in Vietnam: a review. Aquaculture Economics and Management 13 (4), 271-293.

Cashore, B., Gale, F., Meidinger, E., 2006. Forest certification in developing and transitioning countries: part of a sustainable future? Environment 48 (9), 7-25.

Coe, N., et al., 2004. "Globalizing” regional development: a global production networks perspective. Transactions of the Institute of British Geographers 29 (4), 468-484. 
Damette, O., Delacote, P., 2011. Unsustainable timber harvesting, deforestation and the role of certification. Ecological Economics 70 (6), 1211-1219.

Danse, M., Wolters, T., 2003. Sustainable coffee in the mainstream. Greener Management International (43), 37-51.

Davies, I.A., 2007. The eras and participants of fair trade: an industry structure/ stakeholder perspective on the growth of the fair trade industry. Corporate Governance 7 (4), 455-470.

Dolan, C.. Humphrey, J., 2004. Changing governance patterns in the trade in fresh vegetables between Africa and the United Kingdom. Environment and Planning A 36, 491-509.

Driessen, P.P.J., Glasbergen, P., 2002. Greening Society. The Paradigm Shift in Dutch Environmental Politics. Kluwer Academic Publishers, Dordrecht.

Durant, R.F., Fiorino, D.J., O'Leary, R., 2004. Environmental Governance Reconsidered; Challenges, Choices and Opportunities. MIT Press, Cambridge.

Erol, I., Sencer, S., Sari, R., 2011. A new fuzzy multi-criteria framework for measuring sustainability performance of a supply chain. Ecological Economics 70 (6) $1088-1100$

European Commission, 2003. Integrated Product Policy. Building on Environmental Life-Cycle Thinking. Brussels.

Foran, B., Lenzen, M., Dey, C., Bilek, M., 2005. Integrating sustainable chain management with triple bottom line accounting. Ecological Economics 52 (2), 143-157.

Freidberg, S., 2003. Cleaning up down South: supermarkets, ethical trade and African horticulture. Social and Cultural Geography 4 (1), 27-43.

FSC, 2009. Global FSC Certified Forest Area: Type and Distribution. Retrieved October 2009, www.fsc.org.

Gerbens-Leenes, P.W., Moll, H.C., Schoot Uiterkamp, A.J.M., 2003. Design and development of a measuring method for environmental sustainability in food production systems. Ecological Economics 46 (2), 231-248.

Gereffi, G., 1999. International trade and industrial upgrading in the apparel commodity chain. Journal of International Economics 48 (1), 37-70.

Gereffi, G., Humphrey, J., et al., 2005. The governance of global value chains. Review of International Political Economy 12 (1), 78-104.

Glasbergen, P., 1992. Seven steps towards an instrumentation theory for environmental policy. Policy and Politics 20 (3), 191-200.

Glasbergen, P., Groenenberg, M.C., 2001. Environmental partnerships in sustainable energy. Journal of European Environmental Policy 1, 1-13.

GLOBALGAP, 2009. About Us: What is GLOBALGAP?. Retrieved October 2009, www. globalgap.org.

Gobbi, J.A., 2000. Is biodiversity-friendly coffee financially viable? An analysis of five different coffee production systems in western El Salvador. Ecological Economics 33 (2), 267-281.

Goldbach, M., Seuring, S., Back, S., 2003. Coordinating sustainable cotton chains for the mass market - the case of the German mail order business Otto. Greener Management International (43), 65-78.

Gunningham, N., Grabosky, P., 1998. Smart Regulation: Designing Environmental Policy. Clarendon Press, Oxford.

Hall, J., 2000. Environmental supply chain dynamics. Journal of Cleaner Production 8 (6), 455-471.

Hanf, K., Scharpf, F.W., 1978. Interorganizational Policy-Making; Limits to Coordination and Central Control. Sage Publications, London.

Hoogerwerf, A., 1990. Reconstructing policy theory. Evaluation and Program Planning 13 (3), 285-291.

Jordan, A., Wurzel, R.K.W., Zito, A., 2005. The rise of 'new' policy instruments in comparative perspective: has governance eclipsed government? Political Studies 53, 477-496.

Kaplinsky, R., 2000. Globalisation and unequalisation: what can be learned from value chain analysis? Journal of Development Studies 37 (2), 117-146.

Keijzers, G., 2000. The evolution of Dutch environmental policy: the changing ecological arena from 1970-2000 and beyond. Journal of Cleaner Production 8, $179-200$.

Kjaer, A.M., 2004. Governance. Cambridge University Press, Cambridge.

Klok, P.-J., 1989. Beleidsuitvoering en instrumententheorie (Policy implementation and instrument theory). Beleidswetenschap 3 (3), 264-281.

Kok, M.T.J., Brons, J., Witmer, M., with contributions by Klop, P., 2011. A global public goods perspective on environment and poverty reduction. Implications for Dutch foreign policy. PBL report 555075001, PBL Netherlands Environmental Assessment Agency (PBL), Den Haag/Bilthoven, The Netherlands.

Kooiman, J., 2003. Governing as Governance. Sage Publications, London.

KPMG, 2001. Evaluatie van de toepassing van de minimumeisen voor het systeem van vrijwillige houtcertificering. KPMG, Amsterdam.

Laine, E.L., Laine, M., 2009. Finnish World Shops at a crossroads in the commercialized fair trade market. Sustainable Development 17 (5), 274-283.

Lemos, M.C., Agrawal, A., 2006. Environmental governance. Annual Review of Environment and Resources 31, 297-325.

Low, W., Davenport, E., 2005. Postcards from the edge: maintaining the 'alternative' character of fair trade. Sustainable Development 13 (3), 143-153.

Marin, B., Mayntz, B., 1991. Policy Networks. Empirical Evidence and Theoretical Considerations. Campus Verlag, Frankfurt.

Mcdermott, C., Noah, E., Cashore, B., 2008. Differences that "matter?" A framework for comparing environmental certification standards and government policies. Journal of Environmental Policy and Planning 10 (1), 47-70.

Meaton, J., Young, W., 2003. Fair trade as a strategy for international competitiveness. International Journal of Sustainable Development and World Ecology 10 (1), $1-13$

Mefford, R., 2010. Offshoring, lean production and a sustainable global supply chain European Journal of International Management 4 (3), 303-315.
Mintzberg, H., 1987. The strategy concept I: five Ps for strategy. California Management Review 29, 11-24 (Fall).

Mont, O., Dalhammar, C., 2005. Sustainable consumption: at the cross-road of environmental and consumer policies. International Journal of Sustainable Development 8 (4), 258-279.

Muller, C., Vermeulen, W.J.V., Glasbergen, P., 2009. Perceptions on demand side and realities on supply side: a case study on the South African table grape export industry. Sustainable Development 17 (5), 295-310.

Nijdam, D.S., Wilting, H.C., 2003. Milieudruk consumptie in beeld (Environmental Pressure of Consumption). RIVM, Bilthoven.

Oldenburger, J., Leek, N., 2006. Duurzame geproduceerd hout op de Nederlandse markt in 2005. Stichting Probos, Wageningen.

Oldenburger, J., Winterink, A., Leek, N., 2010. Duurzame geproduceerd hout op de Nederlandse markt in 2008 (Sustainably Produced Timber on the Dutch Market 2008). Stichting Probos, Wageningen.

Pagell, M., Wu, Z., 2009. Building a more complete theory of sustainable supply chain management using case studies of 10 exemplars. Journal of Supply Chain Management 45 (2), 37-56.

PBL, 2008. Natuurbalans 2008 (Nature Balance 2008). Planbureau voor de Leefomgeving, Bilthoven.

PBL, 2009. Natuurbalans 2009 (Nature Balance 2009). Planbureau voor de Leefomgeving, Bilthoven.

PEFC, 2009. PECF Council Global Statistics as of August 2009. PEFC news No 44 August 2009 Retrieved October 23, 2009, www.pefc.org.

Perfecto, I., et al., 2005. Biodiversity, yield, and shade coffee certification. Ecological Economics 54 (4), 435-446.

Perl, E., Vorbach, S., 2009. Environmental information for sustainable supply chains. Progress in Industrial Ecology, An International Journal 6 (1), 44-67.

Pierre, J., 2000. Debating Governance. Authority, Steering and Democracy. Oxford University Press, Oxford.

Porter, M., 2011. The big idea: creating shared value. How to reinvent capitalism-and unleash a wave of innovation and growth. Harvard Business Review 89 (1-2).

Potts, J., van der Meer, J., Daitchman, J., 2010. The State of Sustainability Initiatives Review: Sustainability and Transparency. International Institute for Sustainable Development (IISD), Geneva.

Preuss, L., 2009. Addressing sustainable development through public procurement: the case of local government. Supply Chain Management: An International Journal 14 (3), 213-223.

Quakernaat, J., Weenk, A., 1993. Integrated life cycle management at company level: the concept of environmental merit. Journal of Cleaner Production 1 (2), 99-106.

Ras, P., Vermeulen, W.J.V., 2009. Sustainable production and the performance of South African entrepreneurs in a global supply chain. The case of South African table grape producers. Sustainable Development 17 (5), 325-340.

Raynolds, L.T., 2008. Mainstreaming fair trade coffee: from partnership to traceability. World Development 1-11.

Raynolds, L.T., Ngcwangu, S.U., 2010. Fair Trade Rooibos tea: connecting South African producers and American consumer markets. Geoforum 41 (1), 74-83.

Raynolds, L., Murray, D., Heller, A., 2007. Regulating sustainability in the coffee sector: a comparative analysis of third-party environmental and social certification initiatives. Agriculture and Human Values 24 (2), 147-163.

Reuter, C., et al., 2010. Sustainable global supplier management: the role of dynamic capabilities in achieving competitive advantage. Journal of Supply Chain Management 46 (2), 45-63.

Rhodes, R.A.W., 1997. Understanding Governance. Policy Networks, Governance, Reflexivity and Accountability. Open University Press, Buckingham.

Roberts, S., 2003. Supply chain specific? Understanding the patchy success of ethical sourcing initiatives. Journal of Business Ethics 44 (2-3), 159-170.

Rubik, F., Scholl, G., 2002. Integrated product policy (IPP) in Europe - a development model and some implications. Journal of Cleaner Production 10, 507-515.

Schaltegger, S., 2002. A framework for ecopreneurship: leading bioneers and environmental managers to ecopreneurship. Greener Management International (38), $45-58$.

Sell, J., Koellner, T., Weber, O., Pedroni, L., Scholz, R.W., 2006. Decision criteria of European and Latin American market actors for tropical forestry projects providing environmental services. Ecological Economics 58 (1), 17-36.

Seuring, S., 2004. Industrial ecology, life cycles, supply chains: differences and interrelations. Business Strategy and the Environment 13 (5), 306-319.

Seuring, S., Muller, M., 2008. From a literature review to a conceptual framework for sustainable supply chain management. Journal of Cleaner Production 16 (15), 1699-1710.

Seuring, S., Müller, M., 2008. Core issues in sustainable supply chain management - a Delphi study. Business Strategy and the Environment 17 (8), 455-466.

Smith, T.M., Fischlein, M., 2010. Rival private governance networks: competing to define the rules of sustainability performance. Global Environmental Change 20 (2010), 511-522.

Stoker, G., 1998. Governance as theory. Five propositions. International Social Science Journal 50 (1), 17-28.

Svensson, G., 2009. The transparency of SCM ethics: conceptual framework and empirical illustrations. Supply Chain Management: An International Journal 14 (4), 259-269.

Tallontire, A., 2009. Top heavy? Governance issues and policy decisions for the fair trade movement. Journal of International Development 21 (7), 1004-1014.

TCC, 2009. Coffee Barometer. Tropical Commodity Coalition.

Teegen, H., Doh, J., Vachani, S., 2004. The importance of nongovernmental organizations (NGOs) in global governance and value creation: an international business research agenda. Journal of International Business Studies 35 (6), 463-484. 
UtZ Certified, 2010. Small Label, Good Year: UtZ Certified Good Inside Annual Report 2009. UtZ Certified, Amsterdam.

Valkila, J., 2009. Fair Trade organic coffee production in Nicaragua - sustainable development or a poverty trap? Ecological Economics 68 (12), 3018-3025.

van de Graaf, H., Hoppe, R., 1996. Beleid en Politiek; een inleiding tot de beleidswetenschap en de beleidskunde (Policy and Politics: An Introduction to Policy Science). Coutinho, Bussum.

Van Kersbergen, K., Van Waarden, F., 2004. 'Governance' as a bridge between disciplines. European Journal of Political Research 43, 143-171.

Vermeulen, W.J.V., 2002a. Greening production as co-responsibility. In: Driessen, P.P.J., Glasbergen, P. (Eds.), Greening Society. The Paradigm Shift in Dutch Environmental Politics. Kluwer Academic Publishers, Dordrecht, pp. 67-90.

Vermeulen, W.J.V., 2002b. The stubborn consumer. In: Driessen, P.P.J., Glasbergen, P. (Eds.), Greening Society. The Paradigm Shift in Dutch Environmental Politics. Kluwer Academic Publishers, Dordrecht, pp. 91-111.

Vermeulen, W.J.V., 2006. Social dimension of industrial ecology: on the implications of the inherent nature of social phenomena. Progress in Industrial Ecology 3 (6), 574-598.

Vermeulen, W.J.V., 2010. Sustainable supply chain governance systems: conditions for effective market based governance in global trade. Progress in Industrial Ecology, An International Journal 7 (2), 138-162.
Vermeulen, W.J.V., Metselaar, J.A., forthcoming. The performance of sustainable supply chain governance systems: a methodology for assessing system performance and its impact potential.

Vermeulen, W.J.V., Ras, P., 2006. The challenge of greening global product chains: meeting both ends. Sustainable Development 14 (4), 245-256.

Vermeulen, W.J.V., Seuring, S., 2009. Introduction: sustainability through the market: the impacts of sustainable supply chain management. Sustainable Development 17 (5), 269-273.

Vermeulen, W.J.V., van der Waals, J.F.M., Ernste, H., Glasbergen, P., 1997. Duurzaamheid als uitdaging; de afweging van ecologische en maatschappelijke risico's in confrontatie en dialoog (Sustainability as a Challenge: Weighing Ecological and Societal Risks in Confrontation and Dialogue). Sdu Uitgevers, Den Haag.

Vermeulen, W.J.V., Uitenboogaart, Y., Pesqueira, L.D.L., Metselaar, J., Kok, M.T.J., 2010 Roles of Governments in Multi-Actor Sustainable Supply Chain Governance Systems and Effectiveness of their Interventions: An Exploratory Study. Netherlands Environmental Assessment Agency (PBL) and Utrecht University, Bilthoven.

Walker, H., Di Sisto, L., et al., 2008. Drivers and barriers to environmental supply chain management practices: lessons from the public and private sectors. Journal of Purchasing and Supply Management 14 (1), 69-85.

Williamson, O., 2008. Outsourcing: transaction cost economics and supply chain management. Journal of Supply Chain Management 44 (2), 5-16. 